\title{
Erasmus+ in Cologne. Life in Cologne
}

\author{
Cătălina-Teodora STOIAN ${ }^{1}$ \& Vladimir-Nicolae NECHITA ${ }^{2}$ \\ University of Bucharest, Faculty of Geography \\ ${ }^{1}$ ctstoian@yahoo.com, ${ }^{2}$ vladimir.nechita@gmail.com
}

\begin{abstract}
Life in Cologne" is the third and last article of the series "Erasmus+ in Cologne" and is intended mainly for students and researchers of the Faculty of Geography of the University of Bucharest, who want to take part in an Erasmus+ scholarship. It covers advice and relevant information concerning the city of Cologne, the student life there and the nearby destinations that can be visited.
\end{abstract}

Keywords: Erasmus+, Cologne, International Student, Tourist Attraction, Student Life

\section{THE CITY}

When you think about Cologne, you instantly have in mind the image of Cologne Cathedral (Kölner Dom), the symbol of the city (Figure 1), a masterpiece of medieval Gothic architecture and the second most visited tourist attraction in Germany, after the Brandenburg Gate (Brandeburger Tor). The cathedral was built between 1248 and 1473 and it is one of the highest domes in the world, with a height of $157.31 \mathrm{~m}$ (koeln.de, 2018). The church is in a continuous process of restoration, many of the old architectural structures being replaced. For a view over the city, the Hohenzollern Bridge and the Rhine, you can climb up its 533 steps.

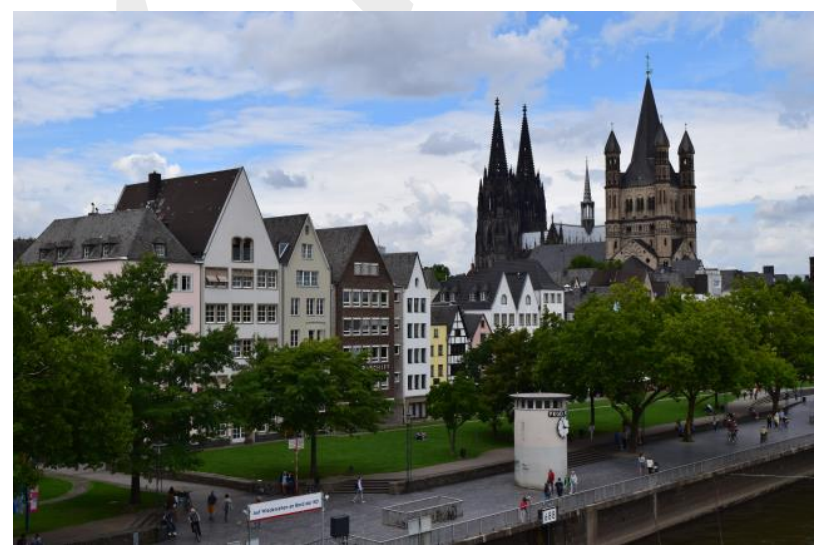

Figure 1 View over the Cathedral and the Old Town
Probably the most beautiful part of the city is the Old Town (Altstadt), located on the left bank of the Rhine. The biggest part of the Old Town was destroyed during the Second World War, but was restored in the following years. Many of the buildings preserve the initial architecture and colors. This part of the city is very popular among tourists, as they can choose between museums, pubs or breweries.

If you are a citizen of Cologne and are registered with the city hall, you have the possibility to visit all museums for free once per month. That day is called Cologne Day and it is the first Thursday of the month, except on public holidays. All you have to do is to present your city registration documents at the entrance. You should start with the Cologne City Museum, where you can discover the history and the evolution of the city, including how the citizens lived here in the past, especially during the Second World War (Figure 2). During this time, almost the whole city was destroyed, excluding the Cologne Cathedral, which miraculously survived, despite of all aerial bombs dropped here during the war.

You can continue your visit at the NSDocumentation Center (The NSDokumentazionszentrum), a place which reveals another period that has left its mark on the city, when the National Socialist German Workers' Party 
ruled in Germany. Here were the headquarters of the Secret State Police for the District of Cologne and a place where many persecutions and executions were made. Currently, the place is also used for the permanent exhibition Cologne during the period of National Socialism.

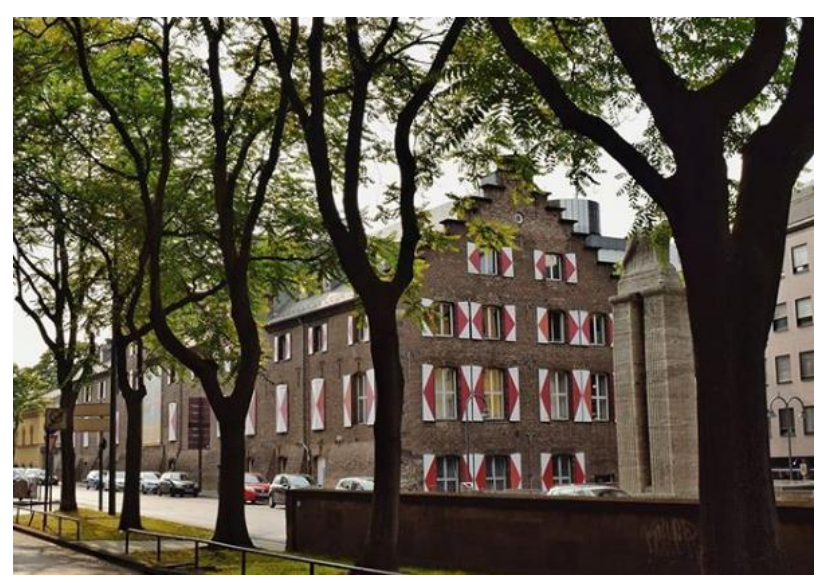

Figure 2 Cologne City Museum

If you love art, you should not miss WallrafRichartz-Museum \& Fondation Corboud, a place where you can admire the widest collection of impressionist and neo-impressionist art in Germany and works of art signed by artists such as Manet, Monet, Renoir, Pissarro, van Gogh, Cézanne, Gauguin, Rubens, Rembrandt, Murillo, Boucher, and also works of the German Romantics and French Realism (Wallraf-Richartz-Museum \& Fondation Corboud, 2018).

If you prefer the modern art instead, then Ludwig Museum is definitely an option to consider. Here can be found representations of the most important modern trend from the beginning of the twentieth century to the present and one of the largest Picasso collections in Europe (Museum Ludwig, 2018).

Cologne is also known among the chocolate lovers for The Chocolate Museum, located in the Rheinau Harbour and offering, besides delicious experiences and information about the history and the culture of chocolate, a beautiful panorama over the city with views over the Old Town and the Cathedral. Although, the best panorama over the city can be experienced from Köln Triangle Panorama, one of the highest buildings in the city and the best spot for watching the sunset and the
Cologne Cathedral. From here you can admire the city through a $360^{\circ}$ panorama.

Not only places and museums are a reason for visiting the city of Cologne, but also the events organized here. Of course there are concerts, festivals or theatre plays, but the highlight of all events is Kölner Lichter, Germany's biggest fireworks spectacle (Figure 3). This event brings joy and wonder in Cologne since 2001 (Culture trip, 2018), being an event of tradition. Its date is set for six years ahead and it is a much awaited event. The fireworks illuminate Cologne's skyline in a show synchronized with music, especially traditional German songs which are sung by everyone present, creating a wonderful atmosphere. The admission is free and people admire this show standing on the banks of the Rhine. You can also buy a ticket for one of the fifty boats that float on the river that night, searching for the best place to admire the fireworks (Cologne Tourism, 2018).

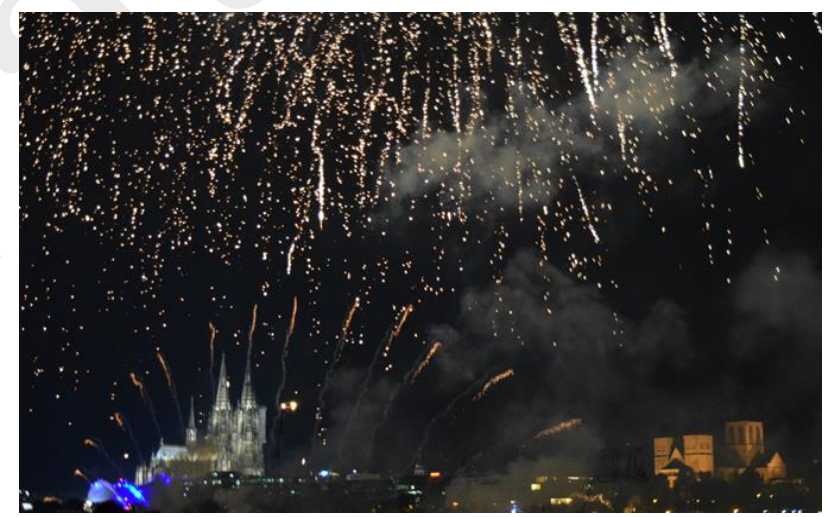

Figure 3 Kölner Lichter 2017

Reggae or hip-hop fans will find Summerjam festival the perfect reason to come to Cologne. This festival is organized annually in the north of the city, at the Fühlinger See (Cologne Tourism, 2018). The gaming community has also an event organized yearly for them, The Gamescom Festival, with more than 300000 visitors from 90 countries per year. Street food festivals like Eat Play Love and the ones that take place in May in Ehrenfeld are also popular, especially among students. Other festivals and celebrations that deserve attention are: Passagen (trends and ideas in design), lit.Cologne (literature festival), Art Cologne (contemporary art), Short Film Festival Cologne, C/O Pop (electronic and pop music festival), Photokina 
(imaging and photography) or Kölner Oktoberfest (Culture trip, 2017).

A visit to Cologne must include also a boat trip on the Rhine and companies like KölnDüsseldorfer, KölnTourist and Colonia offer the possibility to take panorama boat trips from Cologne to Rodenkirchen, Porz or Mülheim (Cologne.de, 2018).

Cologne is home to many vintage flea markets, whereas North Rhine-Westphalia is a perfect place for the urban industry culture. The streets of Cologne host 12 vintage flea markets. Most of them comprise a mix of new and old things with reasonable prices. The Antique Market at the Rheinenergie Stadium is one of the oldest flea market in the state and only old products are sold here. If you are looking for household accessories, old books, vinyl records, accessories or even clothes, you should visit the Stadtflohmarkt at the Uni-Center, which takes place every Saturday all over the year.

All of us might have heard of Eau de Cologne, but few might know that it is originary from Cologne (Kölnisch Wasser) and was invented 1709 by Johann Maria Farina. This is the second symbol of the city of Cologne after the Cathedral and the most famous Eau de Cologne is 4711 Cologne (Figure 4).

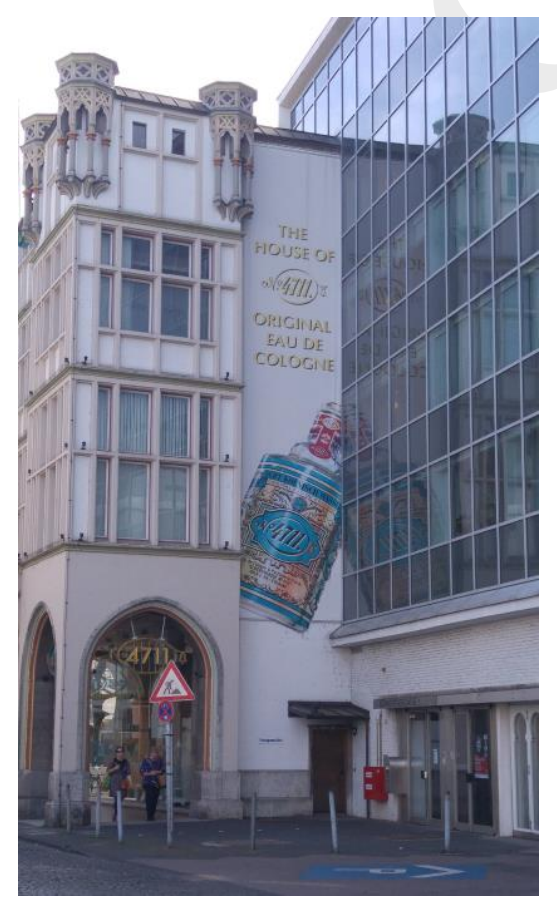

Figure 4 The house of 4711 Eau de Cologne
The Cologne Carnival (Kölner Karneval) takes place yearly and is the biggest event in Cologne. Traditionally, the carnival season is declared open at 11:11 on the eleventh of November. Officially it starts a few weeks before Easter, when parties take place on the streets and in pubs, where closing times are suspended during the festival. When talking about local music, the most known band from Cologne is Kasalla that sings about the city in an original way - kölsch rock. Not least, the local football team, FC Köln, is very appreciated by the fans, having a billy goat as a mascot. The team plays its home games on the RheinEnergieStadion.

\section{STUDENT LIFE}

Maybe the best known place among students is Zülpicher Street (Zülpicher Straße), a street that lies between Zülpicher Place and Gleueler Street, very close to the University of Cologne and to the Student Canteen Zülpicher Street (Mensa Zülpicher Straße). The segment between the Zülpicher Platz and the Universitätsstraße is the crowded one. Day and night students come here to socialize, to relax and to have a good time. There are a lot of restaurants, pubs and clubs in this area, so no matter how you would like to spend your time here, you will not get bored. Theatercafe Filmdose (Zülpicher Str. 39) offers a very delicious and authentic tarte flambée, while the best shawarma is found at Habibi (Zülpicher Str. 28), a very popular place. Very close to the Zülpicher Street, at Hellers brewery (Hellers Brauhaus) you can drink Hellers Kölsch (Figure 5) on draught (Roonstraße 33).

Kölsch is a beer type originally from Cologne and since 1997 it has a protected geographical indication within the European Union (Besch and Profeta, 2002). This beer recipe is very unusual, because it is warm fermented, but kept conditioned at low temperatures like a lager beer (Daniels, 1996). That is why for maximum flavor each glass of Kölsch has to be drunk straight off. The most known Kölsch breweries are Heinrich Reissdorf, Gaffel Becker \& Co and Cölner Hofbräu Früh, and the beer produced by them is sold in almost all stores in Cologne. 


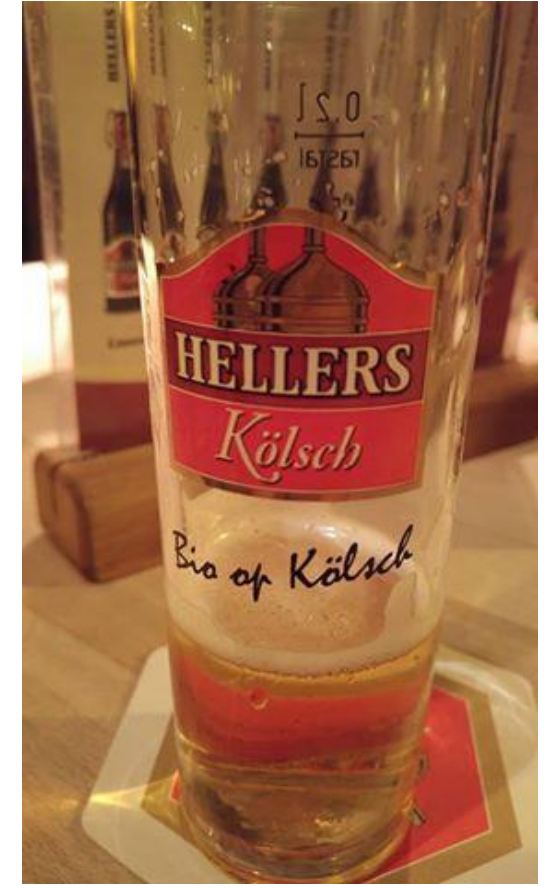

Figure 5 Hellers Kölsch beer on draught

During summer, adults and students gather on both banks of the Rhine and gaze at the city, at the river and at the ships passing by. It is in their culture to drink, especially Kölsch beer, have a snack and listen to music. The right bank of the Rhine is the best spot to look at the opposite side of the city, where the Cathedral lies. If you come here during sunset, you will not regret it.

As a student at TH Cologne you are allowed to eat at the student canteen (Mensa). There are seven student canteens spread around the city (all part of the KSTW - Cologne Student Network):

\section{Mensa Zülpicher Straße}

2. Mensa Robert Koch Straße

3. Mensa Musikhochschule

4. Mensa Deutz

5. Mensa Südstadt

6. Mensa Sportpark Müngersdorf

7. Mensa Gummersbach

8. Mensa Kunsthochschule Medien

All students in Cologne get discount on the menus, but guests can also eat here. The closest student canteen to Campus Deutz is Mensa Deutz, located near the main entrance. It is opened from Monday to Friday for around three hours between 11:30 and 14:30. Periodically, there are also events calledStreetfood@Werk, when a special menu with street food is also available.
Each canteen comprises also a Cafeteria with longer opening hours, where you can buy sandwiches, drinks and snacks. Student canteens have at least 4 different menus daily: 2 meat-based menus (Menü I, Menü II), 1 vegetarian menu (Menü Vegetarisch), 1 special offer menu (Aktionstheke). The prices for students differ from $2.05 €$ to $3.55 €$, while the price range for guests is almost double. The biggest student canteen in Cologne is Mensa Zülpicher Straße, located on the Zülpicher Street. This canteen is made up of three smaller canteens, one of them being opened also during weekends and on evenings.

\section{NEARBY DESTINATIONS}

If you want to discover the surroundings, you can choose to travel by train, as Cologne Main Station is an important local, national and international hub with many connections and one of the busiest stations in Germany. The most important railway company in Germany is Deutsche Bahn AG and you have multiple choices to buy your tickets: online (www.bahn.de), from the vending machines and even through the mobile application $D B$ Navigator. An advantage of being a student in Cologne is the fact that you have the NRWSemesterticket for the whole semester. This ticket allows you to travel through the whole federal state North Rhine-Westphalia for free by all means of transport (except for the IC and ICE trains).

The closest big city to Cologne is Bonn, the former capital of West Germany and the place where Ludwig van Beethoven was born. Maybe the best time to visit this city is in April when the Cherry Blossom Avenue is full of freshly bloomed cherry trees (Figure 6). After visiting the Beethoven House, make sure to see also the Electoral Palace and the Hofgarten, the Bonn Minster and the place where the brand Haribo was invented (Haribo = Hans Riegel Bonn).

On your way back to Cologne, a worth-visiting place is Brühl with its Augustusburg (Figure 7) and Falkenlust Palaces of Baroque and Rococo architecture, both UNESCO cultural World Heritage sites. 


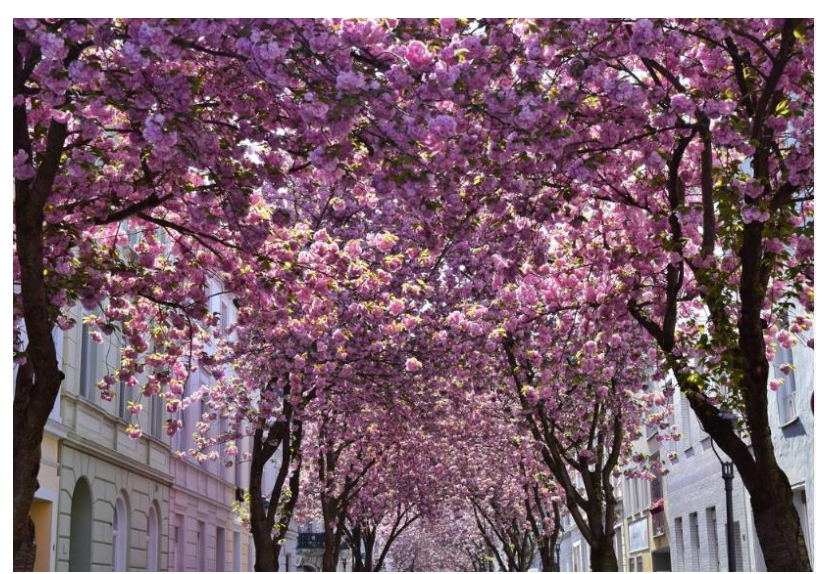

Figure 6 Cherry Blossom Avenue

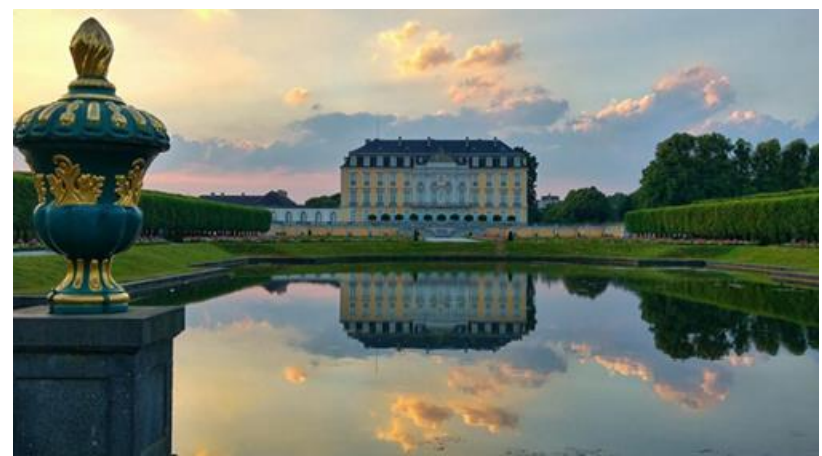

Figure 7 Augustusburg Palace in Brühl

Not far away from Cologne lies Aachen, the westernmost city in Germany, known for the Aachen Cathedral (Aachener Dom), the church of coronation for German kings and queens for almost 600 years (Figure 8). The Aachen City Hall (Aachen Rathaus), the Marketplace (Markt) and the Katschhof are as well worth visiting.

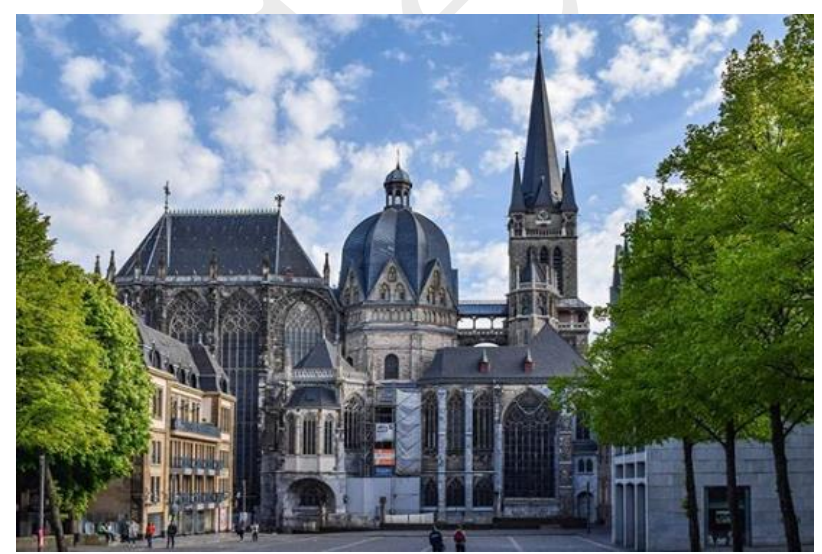

Figure 8 Aachen Cathedral

Three Country Border (Dreiländereck) is a place very close to Aachen, where you can be in three countries at the same time: Germany, Belgium and the Netherlands (Figure 9).

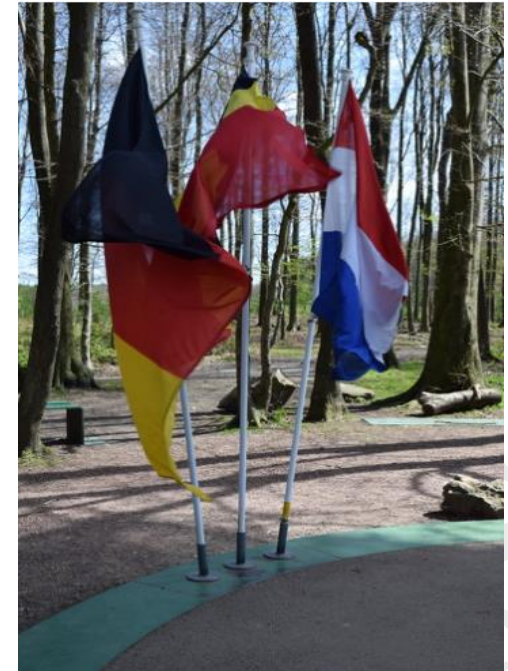

Figure 9 Three Country Border

If you want to discover the natural landscape of the region, the best choice is the Eifel National Park (Nationalpark Eifel), located south of Aachen. You can discover it on your own or on a guided tour with a ranger, on foot, on your bike, on a boat or on horseback. If you are here, do not miss Monschau, known for its idyllic atmosphere and beautiful German houses (Figure 10).

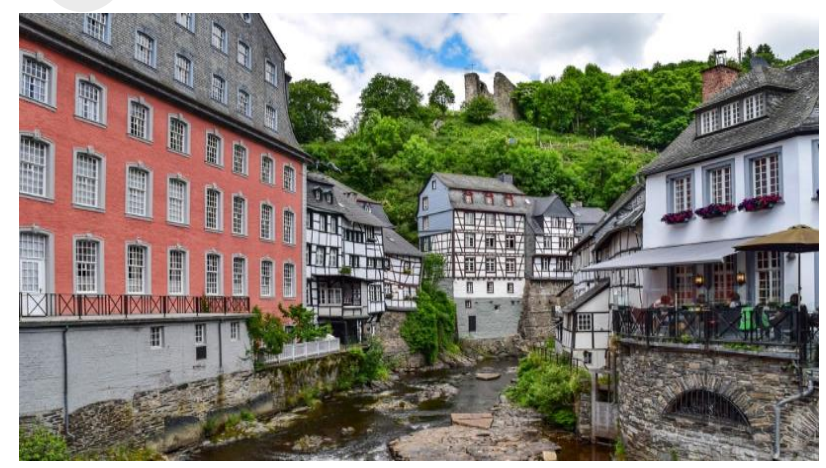

Figure 10 Monschau

Other destinations in the area are Düssseldorf, with its futuristic architecture and the 240 meter high Rhine Tower (Rheinturm), Kettwig (a small, but charming city located on the Ruhr) or Münster (the place where the Treaty of Westphalia was signed).

Another accesible and affordable way of transportation throughout Germany and outside the country is the FlixBus network (www.flixbus.de). This network has hundreds of hubs around Europe and in Cologne the station is located at the CologneBonn Airport. This is a good starting point for 
daytrips or city breaks to cities like Amsterdam, Brussels or Hamburg. All FlixBuses are equipped with Free WiFi. For the best prices it is advisable to book your trip a few weeks before.

\section{CONCLUSION}

No matter how long you will study in Cologne, make sure to get the most out of it, because it is a city with an unique culture. Have fun studying what you like. Travel and experience as much as you can. If you really want to enjoy Cologne as an Erasmus+ student, we recommend you to read also the first two articles of the series: "Prologue" and "TH Cologne".

\section{REFERENCES}

Besch, M., Profeta, A. (2002). Presentation of PDO and $P G I$ in Germany. [online] Available at: http://www.origin-food.org/pdf/olp/olp-de.pdf [Accessed 11 Sep. 2018].

Cologne.de. (2018). Boat trips. [online] Available: https://www.cologne.de/what-to-do/boat-trips.html [Accessed 09 Sep. 2018].
Cologne Tourism. (2018). Germany's biggest fireworks spectacle. [online] Available at: https://www. cologne-tourism.com/see-experience/koelner-lichter [Accessed 08 Aug. 2018].

Culture trip. (2017). Cologne's 9 Underrated Festivals and Celebrations. [online] Available at:https:// theculturetrip.com/europe/germany/articles/colognes9-underrated-festivals-and-celebrations [Accessed 22 Sep. 2018].

Culture trip. (2018). The Best Summer Events in Cologne. [online] Available at: https://theculturetrip. com/europe/germany/articles/the-best-summerevents-in-cologne [Accessed 19 Sep. 2018].

Daniels, R. (1996). Designing Great Beers. Boulder, Colorado: Brewers Publications.

Koeln.de. (2018). Der Kölner Dom. [online] Available at: https://www.koeln.de/tourismus/sehenswertes/koelner _dom [Accessed 23 Sep. 2018].

Museum Ludwig. (2018). Museum. [online] Available at: https://www.museum-ludwig.de/en/museum.html [Accessed 22 Sep. 2018].

Wallraf-Richartz-Museum \& Fondation Corboud. (2018). Information. [online] Available at: https://www. wallraf.museum/en/the-museum/ visitors-information/information [Accesse 28 Sep. 2018]. 